ARTICLE

https://doi.org/10.1038/s41467-018-07985-2

\title{
Iron-catalyzed carboazidation of alkenes and alkynes
}

\author{
Haigen Xiong 1,2, Nagarajan Ramkumar', Mong-Feng Chiou', Wujun Jian', Yajun Li id 1, Ji-Hu Su ${ }^{3}$, \\ Xinhao Zhang (i) ${ }^{4} \&$ Hongli Bao (1) ${ }^{1,2}$
}

Carboazidation of alkenes and alkynes holds the promise to construct valuable molecules directly from chemical feedstock therefore is significantly important. Although a few examples have been developed, there are still some unsolved problems and lack of universal methods for carboazidation of both alkenes and alkynes. Here we describe an iron-catalyzed rapid carboazidation of alkenes and alkynes, enabled by the oxidative radical relay precursor $t$-butyl perbenzoate. This strategy enjoys success with a broad scope of alkenes under mild conditions, and it can also work with aryl alkynes which are challenging substrates for carboazidation. A large number of diverse structures, including many kinds of amino acid precursors, fluoroalkylated vinyl azides, other specific organoazides, and $2 \mathrm{H}$-azirines can be easily produced.

\footnotetext{
${ }^{1}$ Key Laboratory of Coal to Ethylene Glycol and Its Related Technology, State Key Laboratory of Structural Chemistry, Center for Excellence in Molecular Synthesis, Fujian Institute of Research on the Structure of Matter, Chinese Academy of Sciences, 155 Yangqiao Road West, 350002 Fujian, China.

${ }^{2}$ University of Chinese Academy of Sciences, 100049 Beijing, China. ${ }^{3}$ Hefei National Laboratory for Physical Sciences at the Microscale and Department of Modern Physics, CAS Key Laboratory of Microscale Magnetic Resonance, University of Science and Technology of China, 96 Jinzhai Road, 230026 Hefei, China. ${ }^{4}$ Lab of Computational Chemistry and Drug Design, Key Laboratory of Chemical Genomics, Peking University Shenzhen Graduate School, 518055 Shenzhen, China. Correspondence and requests for materials should be addressed to H.B. (email: hlbao@fjirsm.ac.cn)
} 
A mino acids, the basic building blocks of proteins are being used increasingly in bio-relevant modification of proteins and pharmaceutical applications. Development of more versatile methods to provide useful but synthetically challenging amino acid frameworks from chemical feedstocks is always highly desired ${ }^{1-4}$. Carboazidation of alkenes and alkynes holds the promise to construct valuable molecules including amino acid precursors and has therefore attracted much attention recently. Although several carboazidations of alkenes have been developed by Huang ${ }^{5}$, Renaud ${ }^{6,7}, \mathrm{Liu}^{8}$, Masson ${ }^{9}, \mathrm{Zhu}^{10}$, Jiao ${ }^{11}$ and $\mathrm{Xu}^{12}$, there are some unsolved problems in this field. How to realize the carboazidation reaction using nontoxic, inexpensive and readily available reagents with a broad scope of olefins remains a question. In addition, the carboazidation of alkynes is even more challenging than carboazidation of alkenes (Fig. 1a). There is only one successful carboazidation of alkynes reported by Liu ${ }^{13}$ which works for single carbon functionality, i.e., a trifluoromethyl group using Togni's reagent (Fig. 1b). The reason for the lack of methods for carboazidation of alkynes might be attributed to the relative lower efficiency of incorporation of azido species compared to other competing reactions. The development of carboazidation of alkenes and alkynes is significantly important from the synthetic point of view.

$t$-Butyl perbenzoate (TBPB) is a commercially available and inexpensive oxidant frequently used as a precursor of the $t$-butoxyl radical ${ }^{14-22}$. Lately, TBPB has been proved to be a good source of methyl radical by $\mathrm{Yu}^{23}$ and our group ${ }^{4,24,25}$. Although our understanding of the selective formation of methyl radicals is limited, we found previously that in the presence of $\mathrm{Fe}(\mathrm{OTf})_{2}$ or $\mathrm{Fe}(\mathrm{OTf})_{3}$, the methyl radical is formed exclusively. We envisioned that TBPB could serve as a polyfunctional reagent for the carboazidation of alkenes and alkynes. Herein, we report our development of a versatile iron-catalyzed rapid carboazidation of both alkenes and alkynes, enabled by TBPB (Fig. 1c).

\section{Results}

Carboazidation of alkenes. We investigated the reaction parameters for carboazidation in the presence of TBPB and found that ferrous trifluoromethanesulfonate $\left(\mathrm{Fe}(\mathrm{OTf})_{2}\right.$, ferrous triflate) is optimal (Fig. 2, see details in Supplementary Table 1 and Supplementary Figures 2-4), delivering the corresponding product 3 in $89 \%$ yield at $\mathrm{rt}$ with DME (dimethoxyethane) as the solvent and azidotrimethylsilane $\left(\mathrm{TMSN}_{3}\right)$ as the azidation reagent. Possible by-products $4,4^{\prime}$, and $\mathbf{4}^{\prime \prime}$ were not observed.

With the optimized conditions in hand, we studied the scope of the reaction with alkyl iodides (Fig. 3 and Supplementary Figures 5-34). Fluoroalkyl iodides were examined first and the corresponding fluoroalkyl-azidation products $(\mathbf{5}-\mathbf{1 0})$ were obtained in high yields ${ }^{26}$. The reaction of styrene with iodoacetonitrile proceeds smoothly, affording the corresponding product (11) in $86 \%$ yield. Reactions with ethyl iodoacetates affords products (12-14) with the yield ranging from $71-85 \%$. With 1-iodo-3,3-dimethylbutan-2-one the reaction delivers the azide (15) in $61 \%$ yield. Three electron rich alkyl iodides, i.e., 1-chloro-4-iodobutane, 1-iododecane and 2-iodobutane are not

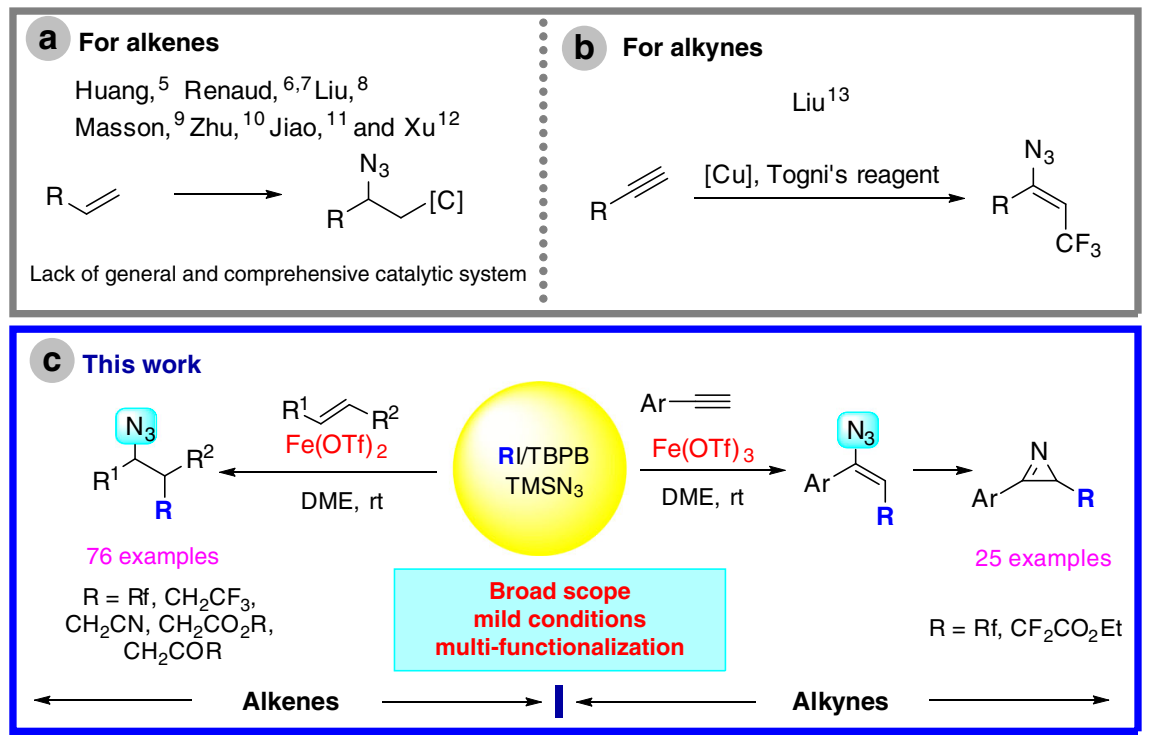

Fig. 1 Carboazidation of alkenes and alkynes. a Previous arts on carboazidation of alkenes. b Previous arts on carboazidation of alkynes. c This work: carboazidation of alkenes and alkynes

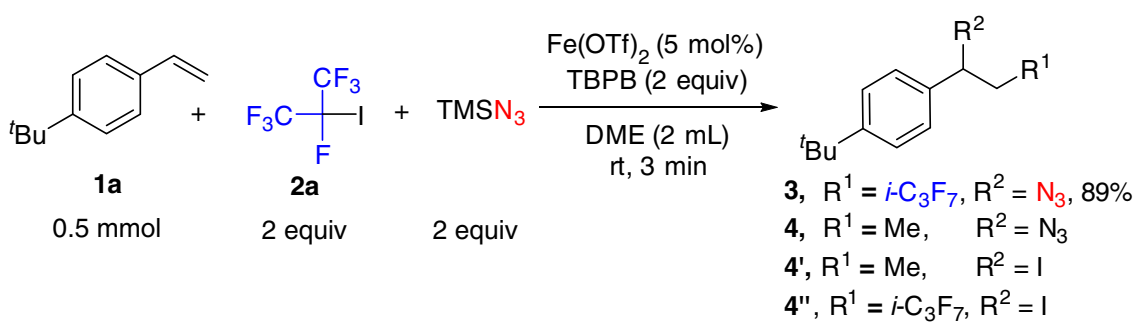

Fig. 2 Optimized conditions for carboazidation of alkenes. Fe(OTf) 2 ( $5 \mathrm{~mol} \%), \mathbf{1 a}(0.5 \mathrm{mmol}), \mathbf{2 a}(1.0 \mathrm{mmol}), \mathrm{TMSN}_{3}(1.0 \mathrm{mmol}), \mathrm{TBPB}(1.0 \mathrm{mmol})$ in DME $(2 \mathrm{~mL})$ at $\mathrm{rt}$ for 3 min under an $\mathrm{N}_{2}$ atmosphere 


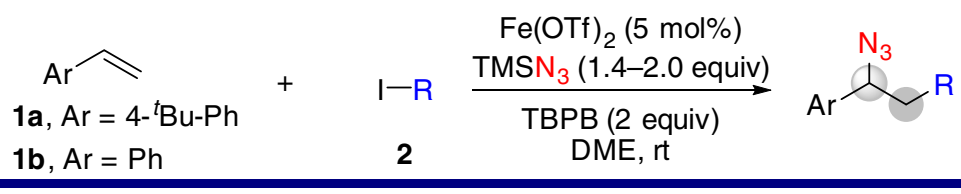<smiles>N#CC=Cc1ccc(Br)cc1</smiles>

$5^{\mathrm{a}}, \mathrm{Rf}=\mathrm{CF}_{3}, \quad 87 \%, 20 \mathrm{~min}$

6, $\mathrm{Rf}=\mathrm{CF}_{2} \mathrm{CF}_{3}, 84 \%, 3 \mathrm{~min}$<smiles>N#CC(=CBr)c1ccccc1</smiles><smiles>[R]CC(C)c1ccccc1</smiles>

$11^{\mathrm{b}}, \mathrm{R}^{\prime}=\mathrm{CH}_{2} \mathrm{CN}, \quad 86 \%, 10 \mathrm{~min}$

12, $\mathrm{R}^{\prime}=\mathrm{CH}_{2} \mathrm{CO}_{2} \mathrm{Et}, 84 \%, 10 \mathrm{~min}$

13, $\mathrm{R}^{\prime}=\mathrm{CF}_{2} \mathrm{CO}_{2} \mathrm{Et}, 85 \%$, $3 \mathrm{~min}$

$14, \mathrm{R}^{\prime}=\mathrm{CHFCO}_{2} \mathrm{Et}, 71 \%, \mathrm{dr}=1: 1,3 \mathrm{~min}$

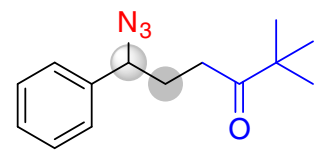

$15,61 \%, 10 \mathrm{~min}$

7, $\mathrm{Rf}^{\prime}=\mathrm{CF}_{2} \mathrm{CF}_{2} \mathrm{Cl}, 87 \%, 3 \mathrm{~min}$

8, $\mathrm{Rf}^{\prime}=n-\mathrm{C}_{4} \mathrm{~F}_{9}, \quad 84 \%, 3 \mathrm{~min}$

9, $\mathrm{Rf}^{\prime}=$ cyc- $\mathrm{C}_{6} \mathrm{~F}_{11}, 93 \%, 3 \mathrm{~min}$

10, $\mathrm{Rf}^{\prime}=\mathrm{CH}_{2} \mathrm{CF}_{3}, 70 \%, 30 \mathrm{~min}$

Fig. 3 Scope of alkyl iodides. General reaction conditions: Fe(OTf) 2 (3-5 mol\%), 1a or $\mathbf{1 b}(0.5 \mathrm{mmol}), 2(0.65-1.0 \mathrm{mmol}), \mathrm{TMSN}_{3}(0.7-1.0 \mathrm{mmol})$, TBPB $(0.75-1.0 \mathrm{mmol})$ in DME $(2 \mathrm{~mL})$ at $\mathrm{rt}$ under an $\mathrm{N}_{2}$ atmosphere. a Instead of TBPB, lauroyl peroxides (LPO, $\left.0.75 \mathrm{mmol}\right)$ was applied. ${ }^{b} 50{ }^{\circ} \mathrm{C}$

effective in this reaction as the direct azidation of alkyl iodides to form alkyl azides occurs. It should be noted that the reactions with perfluoroalkyl iodides are very fast, completing in $10 \mathrm{~min}$ in many cases.

Subsequently, we studied the substrate scope of olefins (Fig. 4 and Supplementary Figs. 35-189). As examples, $\alpha$-azido esters (16-27 in Fig. 4a), $\beta$-azido esters (28-37 in Fig. 4 b), $\gamma$-azido esters (38-63 in Fig. 4c), other azido acid derivatives (64-69 in Fig. $4 \mathrm{~d}-\mathrm{g}$ ) and organoazides (70-75 in Fig. 4h) were obtained. The functional group compatibility of this reaction is good: a series of functional groups, such as halogen, ester, carboxylic acid (69), and free hydroxyl group (74) are tolerated under the reaction conditions. Both terminal and internal alkenes (28-37, 58, and 65) are compatible with the reaction. The carboazidation reactions of 1-octene with iodomethane and iodobutane are not successful under the reaction conditions.

To highlight the synthetic applications, 8, 19 and 78 were reduced to amine $\mathbf{7 6} \mathbf{1}^{11}$, amino acid $77^{26}$ and pyrrolidinone $\mathbf{7 9}$, respectively (Fig. 5 and Supplementary Figs. 190-199).

Carboazidation of alkynes. Vinyl azides (1-azidoalkenes) ${ }^{27,28}$ are versatile building blocks in organic synthesis and have been used in many transformations to synthesize bioactive alkaloids and heterocycles ${ }^{29-36}$. Although the carboazidation of alkynes can difunctionalize alkynes, affording 1-azidoalkenes which can be subsequently converted to $2 \mathrm{H}$-azirines, reports of such efficient methods are rare ${ }^{13}$, and accordingly, we studied the carboazidation of alkynes. After carefully screening the reaction conditions, $\mathrm{Fe}(\mathrm{OTf})_{3}$ was found to be the best catalyst, producing a carboazidation product $(\mathbf{8 1})$ while avoiding the formation of the atomtransfer radical addition (ATRA) product $\left(\mathbf{8 1}^{\prime}\right)$ (Fig. 6a, see details in Supplementary Table 2 and Supplementary Figs. 200208). In view of the broad synthetic utilities of $2 \mathrm{H}$-azirines, the conversion of vinyl azides to $2 H$-azirines was studied. It was found that compound $\mathbf{8 1}$ could be converted into a $2 \mathrm{H}$-azirine (82) in toluene at $120^{\circ} \mathrm{C}$ (Fig. 6b).

With these conditions identified, we studied the substrate scope regarding alkyl iodides and alkynes. The results are shown in Fig. 7 and Supplementary Figs. 209-283. Fluoroalkyl iodides and aryl alkynes react well in these transformations. Reaction of 1 -iododecane with ethynylbenzene does not deliver the desired product. As an example, reaction of 1-octyne delivers only the ATRA product $(\mathbf{1 0 7})^{37}$ in $42 \%$ yield.

To highlight the synthetic applications of this method further, vinyl azides and $2 \mathrm{H}$-azirine were converted to $108^{38} \mathbf{1 0 9}^{39}$ and $\mathbf{1 1 0}^{40}$ in high yields (Fig. 8 and Supplementary Figs. 284-295). The geometry of vinyl azides was confirmed by X-ray crystallographic analysis of product 109 (see details in Supplementary Figure 1 and Supplementary Table 3).

\section{Discussion}

In summary, we have developed a carboazidation of alkenes and alkynes enabled by TBPB. This key transformation has been successfully used to afford various valuable structural skeletons, including many amino acid precursors, vinyl azides and $2 \mathrm{H}$-azirines. It is noteworthy that this carboazidation works for both alkenes and alkynes with multiple carbon functionalities.

\section{Methods}

Typical procedure for carboazidation of alkenes. $\mathrm{Fe}(\mathrm{OTf})_{2}(9 \mathrm{mg}, 0.025 \mathrm{mmol})$ was added to a dried Schlenk tube equipped with a magnetic bar. This tube was then flushed with $\mathrm{N}_{2}$ gas (3 times) and an $\mathrm{N}_{2}$ atmosphere was maintained using an $\mathrm{N}_{2}$ balloon. A thoroughly mixed solution of alkene $(0.5 \mathrm{mmol})$, alkyl iodide $(0.65-1.5 \mathrm{mmol}), \mathrm{TMSN}_{3}(0.7-1.7 \mathrm{mmol})$ and TBPB $(0.75-1.75 \mathrm{mmol})$ in DME $(2 \mathrm{~mL})$ was added to the catalyst by syringe and the mixture was stirred vigorously for 3-120 $\mathrm{min}$ at the appropriate temperature. After completion of the reaction, judged by TLC, the solvent was evaporated and the residue was purified by flash chromatography on silica gel using petroleum ether and EtOAc to give the corresponding product. 
a<smiles>[R]C(N)(C=CC(F)(F)F)C(=O)OCC(CC)C(C)(C)C</smiles>

16, $\mathrm{R}=\mathrm{Me}, 92 \%, \mathrm{dr}=1: 1,3 \mathrm{~min}$ 17, $\mathrm{R}=\mathrm{H}, \quad 66 \%, \mathrm{dr}=1: 1,3 \mathrm{~min}$<smiles>N#CC(=CC(=O)OCc1ccccc1)C(F)(F)F</smiles>

$18,63 \%, 3 \mathrm{~min}$<smiles>CC(N)(C=[In])C(=O)OCc1ccccc1</smiles>

19, $\mathrm{Rf}=n-\mathrm{C}_{4} \mathrm{~F}_{9}, \quad 90 \%, 3 \mathrm{~min}$ 20, $\mathrm{Rf}=i-\mathrm{C}_{3} \mathrm{~F}_{7}, \quad 93 \%, 3 \mathrm{~min}$ 21, $\mathrm{Rf}=\mathrm{CF}_{2} \mathrm{CF}_{2} \mathrm{Cl}, 80 \%, 3 \mathrm{~min}$ 22, $\mathrm{Rf}=n-\mathrm{C}_{6} \mathrm{~F}_{13}, \quad 77 \%, 3 \mathrm{~min}$ 23, $\mathrm{Rf}=n-\mathrm{C}_{8} \mathrm{~F}_{17}, \quad 87 \%, 3 \mathrm{~min}$ 24, $\mathrm{Rf}=n-\mathrm{C}_{10} \mathrm{~F}_{21}, \quad 88 \%, 3 \mathrm{~min}$ 25, $\mathrm{Rf}=\mathrm{CF}_{2} \mathrm{CO}_{2} \mathrm{Et}, 93 \%, 3 \mathrm{~min}$<smiles>CC(N)(CCC#N)C(=O)OCc1ccccc1</smiles>

26, $87 \%, 10 \mathrm{~min}$<smiles>CC(C)(C)OCCCC(C)(N)C(=O)OCc1ccccc1</smiles>

27, $85 \%, 3 \mathrm{~min}$

b<smiles></smiles>

\begin{abstract}
28, $\mathrm{R}=\mathrm{H}, \quad 68 \%, \mathrm{dr}=9: 1, \quad 15 \mathrm{~min}$
29, $\mathrm{R}=3,4-\mathrm{diCl}, \quad 62 \%$, single isomer, $15 \mathrm{~min}$

30, $\mathrm{R}=2-\mathrm{F}-4-\mathrm{Cl}, \quad 68 \%, \mathrm{dr}=12: 1, \quad 15 \mathrm{~min}$ $31, \mathrm{R}=4-\mathrm{CN}, \quad 60 \%$, single isomer, $15 \mathrm{~min}$
\end{abstract}

32, $\mathrm{R}=4-\mathrm{Br}, \quad 70 \%$, single isomer, $15 \mathrm{~min} \quad 35, \mathrm{R}=4-\mathrm{OMe}, 56 \%$, single isomer, $15 \mathrm{~min}$ 33, $\mathrm{R}=4-\mathrm{CO}_{2} \mathrm{Me}, 57 \%$, single isomer, $15 \mathrm{~min} \quad 36, \mathrm{R}=3,4-\mathrm{diF}, 69 \%, \mathrm{dr}=13: 1, \quad 15 \mathrm{~min}$ $34, \mathrm{R}=4-\mathrm{OAc}, \quad 58 \%$, single isomer, $15 \mathrm{~min} \quad 37, \mathrm{R}=4-\mathrm{Me}, \quad 62 \%, \mathrm{dr}=19: 1, \quad 15 \mathrm{~min}$

C<smiles></smiles>

$\mathrm{R}=4-\mathrm{Me}$

$4-t-\mathrm{Bu}$

$3891 \%$

4-OMe

$4-\mathrm{Cl}$

4-F

4-Br

4- $\mathrm{CO}_{2} \mathrm{Me}$

$4-\mathrm{CO}_{2} \mathrm{H}$

4-OAc

4-Ph

3-Me

3-Cl

2-Cl

2,5-diM

3,5- DiCF $_{3}$

$2,3,4,5,6-\mathrm{F}_{5} 56$

$\prod_{\mathrm{O}}^{\mathrm{N}_{3}} \mathrm{CON}_{\mathrm{CN}}^{\mathrm{CO}_{2} \mathrm{Et}} \overbrace{\mathrm{NO}_{2} \mathrm{Et}}^{\mathrm{NO}_{3}}$<smiles>CCOC(=O)CCC(=N)c1ccc2ccccc2c1</smiles>

53, 69\%, $10 \mathrm{~min}$<smiles>CC[SiH2]</smiles><smiles>CCOC(=O)CC1C(=O)c2cccc3cccc1c23</smiles>

Internal olefin

$58,48 \%$ trans, $14 \%$ cis, $30 \mathrm{~min}$<smiles>CCOC(=O)CCC(=N)CCc1ccccc1</smiles>

Unactivated olefin with $\mathrm{ICH}_{2} \mathrm{COOEt}$

59, 65\%, $30 \mathrm{~min}$<smiles>CCCOC(=O)CCC(C)(N)c1ccccc1</smiles>

52, $64 \%, 2 \mathrm{~h}$<smiles>CCOC(=O)CCC(N)(c1ccccc1)c1ccccc1</smiles>

54, 67\%, 2 h<smiles>CCOC(=O)CCC(=N)/C=C/c1ccccc1</smiles>

Diene

$57,77 \%, 10 \mathrm{~min}$

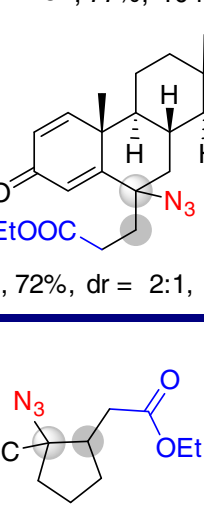

Internal olefin

$65,46 \%, d r=8: 110 \mathrm{~min}$ e<smiles>COC(=O)CC(N)C(=O)OCCC(F)(F)F</smiles>

$67,82 \%, 3 \mathrm{~min}$

f<smiles>CCOC(=O)CCC(N)CC(=O)OC</smiles>

68, $85 \%, 10 \mathrm{~min}$

g<smiles>N=C(CC(N)CC(=O)O)OCC(F)(F)F</smiles>

Unactivated olefin

$69,88 \%, 5 \mathrm{~min}$

h From unactivated olefins<smiles>CC(F)(F)CCC(C#N)C(=O)CBr</smiles>

$70,86 \%, 5 \mathrm{~min}$<smiles>CC(F)(F)CCCCCC(=N)CCC(C)(F)F</smiles>

$71,67 \%, 5 \mathrm{~min}$

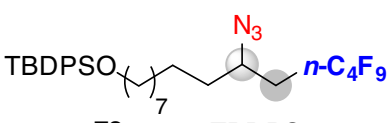

$72,82 \%$, TBDPS = $t$-Butyldiphenylsilyl 5 min

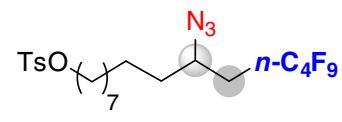

73, $80 \%, 5 \mathrm{~min}$<smiles>CC(F)(F)CCCCC(C#N)=CC(=O)O</smiles>

$74,61 \%, 5 \mathrm{~min}$<smiles>CC(CCNc1ccccc1)NCCC(F)(F)F</smiles>

$75,84 \%, 5 \min$

Fig. 4 Scope of alkenes. a Synthesis of $\alpha$-azido esters. $\mathbf{b}$ Synthesis of $\beta$-azido esters. $\mathbf{c}$ Synthesis of $\gamma$-azido esters. $\mathbf{d}$ Synthesis of $\alpha, \gamma$-azido esters. e Synthesis of an $\alpha, \beta$-azido ester. $\mathbf{f}$ Synthesis of an $\alpha, \beta, \gamma$-azido ester. $\mathbf{g}$ Synthesis of an azido acid. $\mathbf{h}$ Synthesis of other organoazides. General reaction conditions: Fe(OTf) 2 (5 mol\%), 1 (0.5 mmol), 2 (0.65-1.0 mmol), TMSN 3 (1.0 mmol), TBPB (1.0 mmol) in DME $(2 \mathrm{~mL})$ at rt under an $\mathrm{N}_{2}$ atmosphere. Isolated yields. $\mathrm{dr}$ values were determined by ${ }^{1} \mathrm{H}$ NMR 
a<smiles>N#CC(=Cc1ccccc1)C(F)(F)F</smiles>

$\underset{\mathrm{In} \text { (1.5 equiv), } \mathrm{NH}_{4} \mathrm{Cl}(1.5 \text { equiv) }}{\mathrm{CH}_{3} \mathrm{OH}(5 \mathrm{~mL}), \text { reflux, } 5 \mathrm{~h}}$<smiles>NC(=CCC(F)(F)F)c1ccccc1</smiles>

$8,1 \mathrm{mmol}$

76, $91 \%$

b

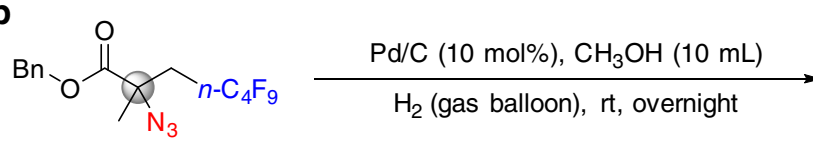<smiles>CC(N)(CC(C(F)(F)F)C(F)(F)F)C(=O)O</smiles>

$19,0.5 \mathrm{mmol}$

$77,97 \%$

C

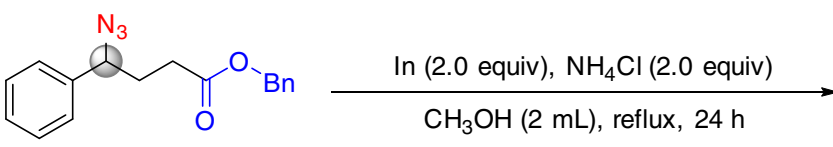<smiles>O=C1CCC(=O)C(c2ccccc2)N1</smiles>

$78,0.5 \mathrm{mmol}$

$79,95 \%$

Fig. 5 Applications of carboazidation products. a Reduction to amine. b Reduction to $\alpha$-amino acid. c Cyclization to pyrrolidinones<smiles>C#Cc1ccc(C(C)C)cc1</smiles>

$80,0.5 \mathrm{mmol} \quad 1.5$ equiv 2 equiv
$\mathrm{Fe}(\mathrm{OTf})_{3}(5 \mathrm{~mol} \%)$ TBPB (2 equiv)

DME (2 mL) it, $20 \mathrm{~min}$ $\mathrm{Ar}=$ 4-propylphenyl

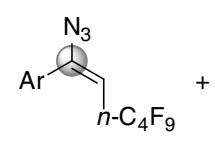

81<smiles>CC(C)=COC(F)(F)F</smiles>

$81^{\prime}$

b

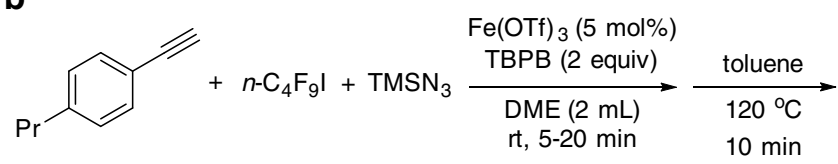<smiles>CCCc1ccc(-c2cc(C(F)(F)F)n[nH]2)cc1</smiles>

$80,0.5 \mathrm{mmol} \quad 1.5$ equiv 2 equiv

82, $60 \%$ yield for two steps

Fig. 6 Carboazidation of alkynes. a Optimized reaction conditions. b Cascade transformation of vinyl azide to $2 \mathrm{H}$-azirine

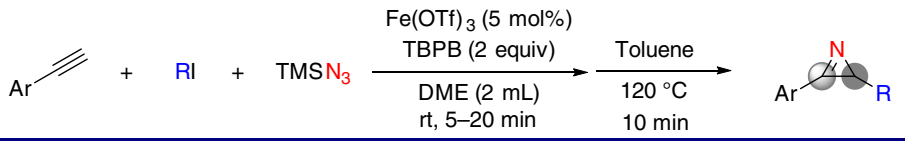

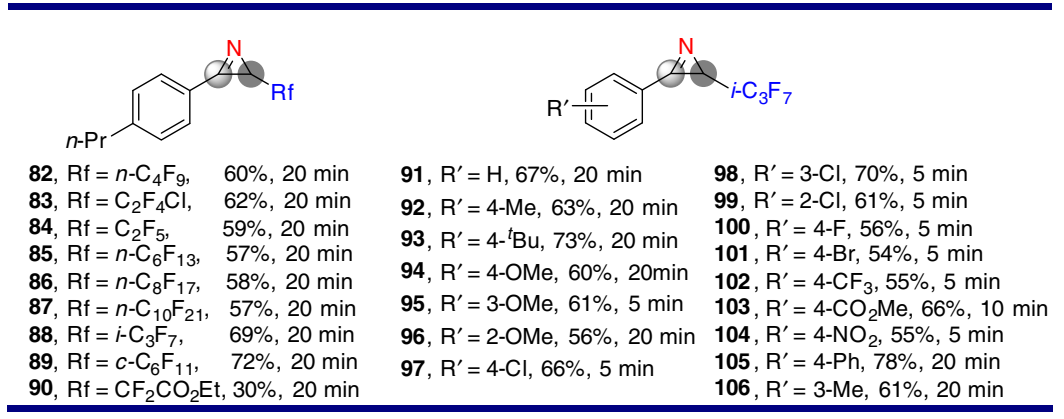

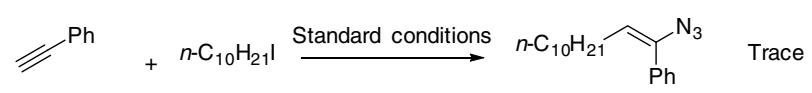

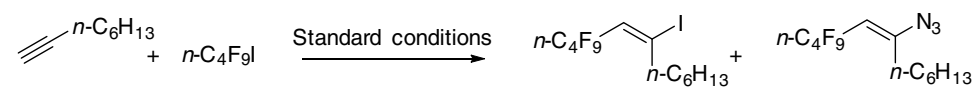

$$
\begin{aligned}
& \text { 107, 42\%, 3.7:1 Trace }
\end{aligned}
$$

Fig. 7 Substrate scope of carboazidation of alkynes and further transformation to $2 \mathrm{H}$-azirines. General reaction conditions: $\mathrm{Fe}(\mathrm{OTf})_{3}(0.025 \mathrm{mmol})$, alkyne $(0.5 \mathrm{mmol}), \mathrm{RI}(0.75 \mathrm{mmol}), \mathrm{TMSN}_{3}(1.0 \mathrm{mmol}), \operatorname{TBPB}(1.0 \mathrm{mmol})$ in DME $(2 \mathrm{~mL})$ at rt for $5-20 \mathrm{~min}$ and then in toluene at $120^{\circ} \mathrm{C}$ for $10 \mathrm{~min}$ under an $\mathrm{N}_{2}$ atmosphere. Isolated yields 
a
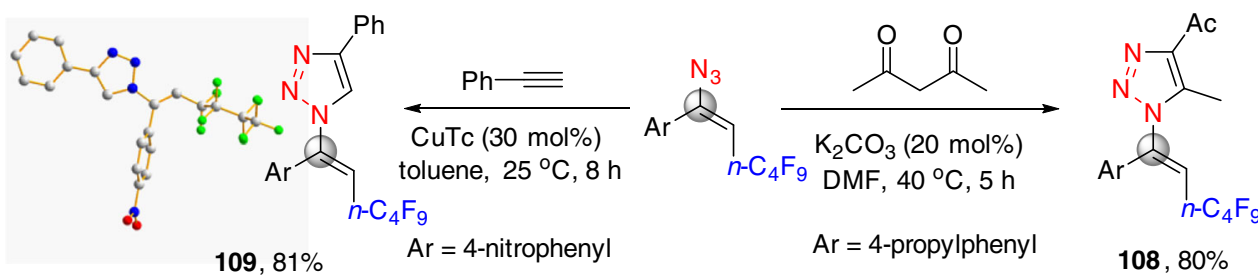

$109,81 \%$

$\operatorname{Ar}=4$-propylphenyl

$108,80 \%$
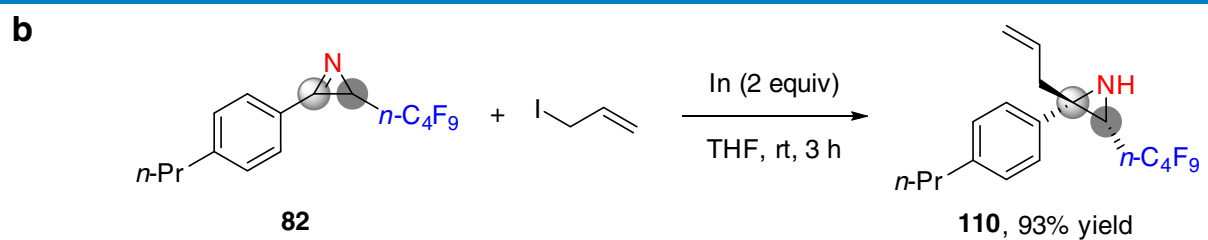

$110,93 \%$ yield

Fig. 8 Further synthetic transformations. a Synthesis of 1,2,3-triazoles. b Synthesis of aziridine

Typical procedure for carboazidation of alkynes. $\mathrm{Fe}(\mathrm{OTf})_{3}(12.7 \mathrm{mg}, 0.025$ mmol) was added to a dried Schlenk tube equipped with a magnetic bar. Then this tube was flushed with $\mathrm{N}_{2}$ (3 times) and an $\mathrm{N}_{2}$ atmosphere was maintained using an $\mathrm{N}_{2}$ balloon. A thoroughly mixed solution of alkyne $(0.5 \mathrm{mmol}), \mathrm{R}_{\mathrm{f}} \mathrm{I}(0.75 \mathrm{mmol})$, $\mathrm{TMSN}_{3}(1.0 \mathrm{mmol})$ and TBPB $(1.0 \mathrm{mmol})$ in DME $(2 \mathrm{~mL})$ was added to the catalyst by syringe and the mixture was stirred vigorously for $5-20 \mathrm{~min}$ at $\mathrm{rt}$. After completion of the reaction, judged by TLC, the volatile compounds were removed by pump and the residue was dissolved in toluene $(3 \mathrm{~mL})$. The resulting mixture was then stirred at $120^{\circ} \mathrm{C}$ for $10 \mathrm{~min}$. The solvent was then evaporated and the residue was purified by flash chromatography on silica gel using petroleum ether and EtOAc to give the corresponding product.

\section{Data availability}

Detailed experimental procedures and characterization of compounds can be found in the Supplementary Information. The X-ray crystallographic coordinates for structures reported in this article have been deposited at the Cambridge Crystallographic Data Centre (109: CCDC 1864994). These data could be obtained free of charge from The Cambridge Crystallographic Data Centre via www.ccdc.cam.ac.uk/data_request/cif. All data are available from the authors upon request.

Received: 26 January 2018 Accepted: 23 November 2018 Published online: 10 January 2019

\section{References}

1. Cheng, J., Qi, X., Li, M., Chen, P. \& Liu, G. Palladium-catalyzed intermolecular aminocarbonylation of alkenes: efficient access of beta-amino acid derivatives. J. Am. Chem. Soc. 137, 2480-2483 (2015).

2. Piou, T. \& Rovis, T. Rhodium-catalysed syn-carboamination of alkenes via a transient directing group. Nature 527, 86-90 (2015).

3. Lerchen, A., Knecht, T., Daniliuc, C. G. \& Glorius, F. Unnatural amino acid synthesis enabled by the Regioselective Cobalt(III)-catalyzed intermolecular carboamination of alkenes. Angew. Chem. Int. Ed. 55, 15166-15170 (2016).

4. Qian, B., Chen, S., Wang, T., Zhang, X. \& Bao, H. Iron-catalyzed carboamination of olefins: synthesis of amines and disubstituted beta-amino acids. J. Am. Chem. Soc. 139, 13076-13082 (2017).

5. Huang, W.-Y. \& Lü, L. The reaction of perfluoroalkanesulfinates VII. Fenton reagent-initiated addition of sodium perfluoroalkanesulfinates to alkenes. Chin. J. Chem. 10, 365-372 (1992).

6. Renaud, P., Ollivier, C. \& Panchaud, P. Radical carboazidation of alkenes: an efficient tool for the preparation of pyrrolidinone derivatives. Angew. Chem. Int. Ed. 41, 3460-3462 (2002).

7. Weidner, K., Giroult, A., Panchaud, P. \& Renaud, P. Efficient carboazidation of alkenes using a radical desulfonylative azide transfer process. J. Am. Chem. Soc. 132, 17511-17515 (2010).

8. Wang, F., Qi, X., Liang, Z., Chen, P. \& Liu, G. Copper-catalyzed intermolecular trifluoromethylazidation of alkenes: convenient access to $\mathrm{CF}_{3}$ containing alkyl azides. Angew. Chem. Int. Ed. 53, 1881-1886 (2014).

9. Dagousset, G., Carboni, A., Magnier, E. \& Masson, G. Photoredox-induced three-component azido- and aminotrifluoromethylation of alkenes. Org. Lett. 16, 4340-4343 (2014).
10. Bunescu, A., Ha, T. M., Wang, Q. \& Zhu, J. Copper-catalyzed threecomponent carboazidation of alkenes with acetonitrile and sodium azide. Angew. Chem. Int. Ed. 56, 10555-10558 (2017).

11. Geng, X., Lin, F., Wang, X. \& Jiao, N. Azidofluoroalkylation of alkenes with simple fluoroalkyl iodides enabled by photoredox catalysis. Org. Lett. 19, 4738-4741 (2017).

12. Zhu, C.-L. et al. Iron(II)-Catalyzed Azidotrifluoromethylation of Olefins and N-heterocycles for expedient vicinal trifluoromethyl amine synthesis. ACS Catal. 8, 5032-5037 (2018).

13. Wang, F., Zhu, N., Chen, P., Ye, J. \& Liu, G. Copper-catalyzed trifluoromethylazidation of alkynes: efficient access to $\mathrm{CF}_{3}$-substituted azirines and aziridines. Angew. Chem. Int. Ed. 54, 9356-9360 (2015).

14. Tang, S. et al. Iodine-catalyzed radical oxidative annulation for the construction of dihydrofurans and indolizines. Org. Lett. 17, 2404-2407 (2015).

15. Kochi, J. K. \& Mains, H. E. Studies on the mechanism of the reaction of peroxides and alkenes with copper salts. J. Org. Chem. 30, 1862-1872 (1965).

16. Pryor, W. A. \& Hendrickson, W. H. Reaction of nucleophiles with electron acceptors by $\mathrm{SN}_{2}$ or electron transfer (ET) mechanisms: tert-butyl peroxybenzoate/dimethyl sulfide and benzoyl peroxide/N,N-dimethylaniline systems. J. Am. Chem. Soc. 105, 7114-7122 (1983).

17. Sekar, G., Dattagupta, A. \& Singh, V. K. Asymmetric Kharasch Reaction: Catalytic Enantioselective Allylic Oxidation of Olefins Using Chiral Pyridine Bis(diphenyloxazoline)-Copper Complexes andtert-Butyl Perbenzoate. J. Org. Chem. 63, 2961-2967 (1998).

18. Kharasch, M. S. \& Sosnovsky, G. The reactions of t-Butyl perbenzoate and olefins-a stereospecific reaction. J. Am. Chem. Soc. 80, 756-756 (1958).

19. Cai, Z. J. et al. $\mathrm{I}_{2} / \mathrm{TBPB}$ mediated oxidative reaction of $\mathrm{N}$-tosylhydrazones with anilines: practical construction of 1,4-disubstituted 1,2,3-triazoles under metal-free and azide-free conditions. Org. Lett. 16, 5108-5111 (2014).

20. Chen, W., Zhang, Y., Li, P. \& Wang, L. tert-Butyl peroxybenzoate mediated formation of 3-alkylated quinolines from $\mathrm{N}$-propargylamines via a cascade radical addition/cyclization reaction. Org. Chem. Front. 5, 855-859 (2018).

21. Yu, H., Li, Z. \& Bolm, C. Nondirected copper-catalyzed sulfoxidations of benzylic C-H bonds. Org. Lett. 20, 2076-2079 (2018).

22. Shen, S.-J., Zhu, C.-L., Lu, D.-F. \& Xu, H. Iron-catalyzed direct olefin diazidation via peroxyester activation promoted by nitrogen-based ligands. ACS Catal. 8, 4473-4482 (2018)

23. Guo, S., Wang, Q., Jiang, Y. \& Yu, J. T. tert-Butyl peroxybenzoate-promoted alpha-methylation of 1,3-dicarbonyl compounds. J. Org. Chem. 79, 11285-11289 (2014).

24. Zhu, N., Zhao, J. \& Bao, H. Iron catalyzed methylation and ethylation of vinyl arenes. Chem. Sci. 8, 2081-2085 (2017).

25. Jian, W., Ge, L., Jiao, Y., Qian, B. \& Bao, H. Iron-catalyzed decarboxylative alkyl etherification of vinylarenes with aliphatic acids as the alkyl source. Angew. Chem. Int. Ed. 56, 3650-3654 (2017).

26. Green, J. E., Bender, D. M., Jackson, S., O'donnell, M. J. \& Mccarthy, J. R. Mitsunobu approach to the synthesis of optically active alpha,alphadisubstituted amino acids. Org. Lett. 11, 807-810 (2009).

27. Chiba, S. Application of organic azides for the synthesis of nitrogencontaining molecules. Synlett 2012, 21-44 (2011).

28. Jung, N. \& Brase, S. Vinyl and alkynyl azides: well-known intermediates in the focus of modern synthetic methods. Angew. Chem. Int. Ed. 51, 12169-12171 (2012). 
29. Wang, Y. F. \& Chiba, S. Mn(III)-mediated reactions of cyclopropanols with vinyl azides: synthesis of pyridine and 2-azabicyclo[3.3.1]non-2-en-1-ol derivatives. J. Am. Chem. Soc. 131, 12570-12572 (2009).

30. Wang, Y. F., Toh, K. K., Lee, J. Y. \& Chiba, S. Synthesis of isoquinolines from alpha-aryl vinyl azides and internal alkynes by $\mathrm{Rh}-\mathrm{Cu}$ bimetallic cooperation. Angew. Chem. Int. Ed. 50, 5927-5931 (2011)

31. Chen, F., Shen, T., Cui, Y. \& Jiao, N. 2,4- vs 3,4-disubsituted pyrrole synthesis switched by copper and nickel catalysts. Org. Lett. 14, 4926-4929 (2012).

32. Chiba, S., Wang, Y. F., Lapointe, G. \& Narasaka, K. Synthesis of polysubstituted $\mathrm{N}-\mathrm{H}$ pyrroles from vinyl azides and 1,3-dicarbonyl compounds. Org. Lett. 10, 313-316 (2008).

33. Li, X., Liao, S., Wang, Z. \& Zhang, L. Ligand-accelerated gold-catalyzed addition of in situ generated hydrazoic acid to alkynes under neat conditions. Org. Lett. 19, 3687-3690 (2017).

34. Forster, M. O. \& Newman, S. H. CCLXIII.-The triazo-group. Part XV. Triazoethylene (vinylazoimide) and the triazoethyl halides. J. Chem. Soc. Trans. 97, 2570-2579 (1910).

35. Liu, Z., Liao, P. \& Bi, X. General silver-catalyzed hydroazidation of terminal alkynes by combining TMS- $\mathrm{N}_{3}$ and $\mathrm{H}_{2} \mathrm{O}$ : synthesis of vinyl azides. Org. Lett. 16, 3668-3671 (2014).

36. Hassner, A. \& Fowler, F. W. A. General synthesis of vinyl azides from olefins. Stereochemistry of elimination from beta-Iodo azides. J. Org. Chem. 33, 2686-2691 (1968).

37. Xu, T., Cheung, C. W. \& Hu, X. Iron-catalyzed 1,2-addition of perfluoroalkyl iodides to alkynes and alkenes. Angew. Chem. Int. Ed. 53, 4910-4914 (2014).

38. Ng, E. P. J., Wang, Y.-F., Hui, B. W.-Q., Lapointe, G. \& Chiba, S. Orthogonal synthesis of pyrroles and 1,2,3-triazoles from vinyl azides and 1,3-dicarbonyl compounds. Tetrahedron 67, 7728-7737 (2011).

39. Liu, Z. et al. Silver(I)-catalyzed hydroazidation of ethynyl carbinols: synthesis of 2-azidoallyl alcohols. Angew. Chem. Int. Ed. 53, 5305-5309 (2014).

40. Hirashita, T., Toumatsu, S., Imagawa, Y., Araki, S. \& Setsune, J.-I. Stereoselective allylation of azirines with allylindium reagents. Tetrahedron Lett. 47, 1613-1616 (2006).

\section{Acknowledgements}

We thank the National Key R\&D Program of China (Grant No.

2017YFA0700103 and 2018YFA0306600), the NSFC (Grant Nos. 21502191, 21672213,

21871258), the Strategic Priority Research Program of the Chinese Academy of Sciences
(Grant No. XDB20000000), the Haixi Institute of CAS (Grant No. CXZX-2017-P01) for financial support. We also thank Professors Daqiang Yuan, Weiping Su, and Tianlu Sheng from our institute for their suggestions.

\section{Author contributions}

H.X., N.R., and W.J. performed the synthetic experiments and analyzed the experimental data. H.B. directed the investigations and prepared the manuscript. H.X., M.-F.C., X.Z., J.-H.S., and Y.L. contributed to the discussion and preparation of the manuscript.

\section{Additional information}

Supplementary Information accompanies this paper at https://doi.org/10.1038/s41467018-07985-2.

Competing interests: The authors declare no competing interests.

Reprints and permission information is available online at http://npg.nature.com/ reprintsandpermissions/

Journal peer review information: Nature Communications thanks the anonymous reviewers for their contribution to the peer review of this work.

Publisher's note: Springer Nature remains neutral with regard to jurisdictional claims in published maps and institutional affiliations.

cc (i) Open Access This article is licensed under a Creative Commons Attribution 4.0 International License, which permits use, sharing, adaptation, distribution and reproduction in any medium or format, as long as you give appropriate credit to the original author(s) and the source, provide a link to the Creative Commons license, and indicate if changes were made. The images or other third party material in this article are included in the article's Creative Commons license, unless indicated otherwise in a credit line to the material. If material is not included in the article's Creative Commons license and your intended use is not permitted by statutory regulation or exceeds the permitted use, you will need to obtain permission directly from the copyright holder. To view a copy of this license, visit http://creativecommons.org/ licenses/by/4.0/.

(C) The Author(s) 2019 